\title{
Special considerations of demolition of the buildings and structures constructed without a permit on the state-owned land parcel restricted for construction
}

\section{Introduction}

This article discusses the legal instruments used against unauthorized constructions on parcels of land owned by the state or a municipal entity; the problems of implementing them in practice; also legal mechanisms of suspending enforcement of decisions on demolition and the defects of law revealed in the process of making decisions on demolition by construction supervision authorities and suspending demolition in the court practice. The present article aims to spotlight certain problems and on the one hand to recommend the legislator ways of solving them and, on the other hand, to advise courts on the criteria to be taken into consideration in the process of making decision on suspending demolition. Some changes in the procedural law which can ensure the shortening of the time of court procedures are also offered.

\section{Problem of illegal construction}

Unauthorized construction implies construction of buildings and structures subject to construction permit without a construction permit and/ or placement of a temporary building or structure after the expiry of the 
construction period determined in the permit certificate. ${ }^{1}$ Unauthorized construction is a construction law offence and is, as a rule, subject to sanctions and the obligation to correct the unlawful act either by its demolition or procurement of the required documents/permits. Failure to correct the offence within the established time limits leads to a triple penalty, as well as demolition of the building and structure constructed without a permit. The problem of illegal construction in Georgia is mainly observed in suburban areas of large cities, particularly Tbilisi. The practice of recent years has shown that illegal construction was carried out in central districts of the city, too. Illegal construction causes significant problems particularly when it is carried out on the territory owned by the state or a self-governing unit. Notably, such problems are not common only for Georgia. For example, a legislative regulation governing unauthorized construction on the city-owned lands was initiated in the Canadian city Wetaskiwin on July 17, 2017 because earlier law had not envisaged penalty sanctions for this kind of act. ${ }^{2}$

Decree No 660 of the President of Georgia dated November 24, 2007 according to which constructions carried out before January 1, 2007 were subject to legalization became one of the factors stimulating unauthorized constructions in Georgia - thus becoming a legal way of avoiding responsibility. Also, the Law on "Recognition of ownership right to land parcels owned (used) by natural persons and legal entities of public law" was adopted on July 11, 2007 allowing to register the right of ownership on state-owned land parcels illegally occupied until January 1, 2007. Thus, these two normative acts allowed for legalization of both the right of ownership on the illegally occupied state-owned land parcels and unauthorized constructions on them. As a whole, the main drawback of the regulations in force is their unlimited effect (both normative acts are in force until now), while the state authorities did not have a technical capacity to truly prove that fencing (occupation) of the land parcel and construction on it had actually been carried out before January 1, 2007. Namely, this problem was caused by the absence of high quality aerial surveying of the Georgian cities by January 1, 2007. This, in consequence, allowed to manipulate the regulation by just providing witnesses who attested that the works had been finalized before January 1, 2007.

\footnotetext{
${ }^{1}$ Homogenous practice of the Supreme Court of Georgia regarding disputes arising out of construction relations, Tbilisi 2018, p. 40.

${ }^{2}$ City moving toward fines for construction on public property without permit, Real Estate Monitor Worldwide; Amman: SyndiGate Media Inc. Aug 5, 2017, p. 1-3.
} 
Therefore, technical support is an important factor for proving facts. One of the examples of its usefulness may be taken from the Polish practice. Although the owner of a car wash illegally constructed in the city of Poznan claimed that the construction was carried out before January 1 , 1995, the aerial survey performed in 1994-1995 proved (beyond doubt) to the contrary. ${ }^{3}$ Notably, provisions similar to those adopted in Georgia regarding legalization of unauthorized buildings and structures were also introduced in Ukraine, with the time limit until January 30, 2013. During this period the unauthorized constructions had to be legalized, otherwise, sanctions were to be used against illegal investors. ${ }^{4}$

Military conflicts that turned hundreds of thousands of inhabitants into refugees have also contributed to state property theft in the suburbs of Tbilisi and unauthorized construction of houses on it. This construction was performed by one (construction) company in the central districts of the city in 2015-2017. According to the Mayor of Tbilisi, the company was responsible for 14 illegal constructions ${ }^{5}$. It is noteworthy that a similar problem is particularly pressing in China where unauthorized construction of garages due to lack of parking places and/or construction of buildings and structures without a permit for renting them to low-income persons arriving to metropolitan cities from various provinces are named as two main reasons for carrying out construction without a permit on the state-owned land in metropolitan cities. ${ }^{6}$

\section{Legal framework of demolition of unauthorized construction carried out on the land owned by the state and/or self-governing unit}

In connection with unauthorized constructions on land parcels owned by the state and self-governing units, rather than the strictness of penalty sanctions, the extent of enforceability of the decision on demolition of

\footnotetext{
${ }^{3}$ Powiatowy Inspektor Nadzoru Budowlanego dla Miasta Poznania, DECYZJA \#242/2014, 13.06.2014.

${ }^{4}$ Economic Policy; Legalizing Constructions Built Without Permits To Add 4-5 Msq Mof Space In 2011, Says Deputy Minister, Interfax: Ukraine Business Weekly; Kiev, 27 VII 2011.

${ }^{5}$ https://1tv.ge/news/kakha-kaladze-svetis-ert-ert-damfudznebels-kanonisa-dadazaralebuli-moqalaqeebis-winashe-pasukhisgeba-mouwevs/ (accessed: 8 X 2018).

${ }^{6}$ Du Peipei, How Markets Can Solve China's Illegal Building Problem, 15 I 2018, http:// www.sixthtone.com/news/1001551/how-markets-can-solve-chinas-illegal-buildingproblem (accessed: 8 X 2018).
} 
unauthorized buildings in terms of elimination of the offence, i.e. the level of achievement of demolition of a building or structure is more important, because it directly relates to the extent and effectiveness of the protection and exercising by the state government of its ownership rights which may be related to the public order and maintaining safe and healthy environment, etc. Some countries may seem to have resolved this problem simply by using criminal sanctions against the offenders. For example, in Malaysia, even an arrangement of light structures in public areas is punishable under Criminal Law, ${ }^{7}$ and in Cyprus, unauthorized construction, including reconstruction (development) of the privately owned legal building and structure is also viewed as a criminal offence. ${ }^{8}$

The liability for unauthorized construction in Georgia is envisaged by Article 44 of the "Product Safety and Free Movement Code" which differentiates the cases of unauthorized construction. In particular, the strictest liability is imposed for unauthorized construction on real estate owned by the state or a self-governing unit if it was carried in a special construction zone, including Tbilisi, in the cultural heritage protection zone, on the territories established by the law on forest funds and/or water and resort-recreation zones.

Notably, the Georgian legislation does not impose particular liability for cases when unauthorized construction is carried out on the territories where construction is restricted by the general plan of using urban land parcels. Accordingly, liability for such acts within the territory of Tbilisi is imposed based on the above article.

Unauthorized construction on the land owned by the state or a self-governing unit, regardless of when it was carried out (if it is not legalized) is subject to liability in accordance with paragraph "a" of Article 44. In connection with one case, the Cassation Chamber explained that by its nature, unauthorized construction represents a continuous offence. It continues uninterruptedly and is considered to be continued until it is eliminated within legal framework. In the reviewed case, the disputable construction, was regarded as continuously violating the respective legislation until its elimination, while the misconduct existed. ${ }^{9}$

${ }^{7}$ Illegal structures in public space, 13 III 2016, https://www.thestar.com.my/opinion/ letters/2013/03/26/illegal-structures-in-public-space/ (accessed: 8 X 2018).

${ }^{8}$ Demolition of an illegal building, 3 VI 2018, https://cyprus-mail.com/2018/06/03/ demolition-of-an-illegal-building/ (accessed: 8 X 2018).

${ }^{9}$ Homogenous practice of the Supreme Court of Georgia regarding disputes arising out of construction relations, Tbilisi 2018, p. 59. 
Accordingly, the construction control bodies are obliged to conduct the applicable administrative proceedings on construction law offence even if the construction was completed (several dozens of) years ago. The 2 month limitation period ${ }^{10}$ in the proceedings for the construction offence shall be counted from preparing the inspection report after expiry of the reasonable time limit defined by the instruction ${ }^{11}$ for eliminating the offence. In case of expiry of the above term, the construction control body loses the right to use the penalty sanction and shall be obliged to carry out only the measures required for the elimination of the offence in respect to the offender, including demolition.

In accordance with parts 3 and 4 of Article 25 of the Product Safety and Free Movement Code, particular rules of construction offence proceedings are established for the land parcel owned by the state or self-governing unit for an illegal construction:

a) carried out by unidentified person;

b) when the offender is identified;

Several legislative acts were effective in the field of construction control in Georgia and they governed supervision over construction activities, defined the content of construction offences and the proceedings related to construction offence. ${ }^{12}$ These norms have been included in the "Product Safety and Free Movement Code" of May 8, 2012. It should be mentioned that the regulations existing before May 8, 2012 governed these issues in a different way, in particular, the control body did not have any legal mechanisms for demolition of the unauthorized construction whose performer could not be identified, and an appeal of the

${ }^{10}$ According to part 13 of Article 25 of Product Safety and Free Movement Code: "Within two months after drawing up an inspection report, a state construction supervision body shall be obliged to make a decision regarding construction proceedings. A hearing official shall be entitled on reasonable grounds to extend the time limit for consideration of the proceeding. The time limit for consideration may be extended by no more than two months."

${ }^{11}$ Giving an instruction is one of the key conditions in the Georgian construction law and lawfulness of any proceedings are based on the factual circumstance whether the control body gave reasonable time limit to the offender for voluntary elimination of the offence.

${ }^{12}$ From 14 XI 1997 to 10 IV 2010 the Law of Georgia "On State Supervision of Architectural-Construction Activities" was in force in the field of construction control in Georgia and this law governed the issues of supervision of construction activities, defined the content of construction offences and rules of construction offence proceedings. On 19 IV 2010 it was replaced by the Law "On Technical Threat Control" and the latter was annulled by "Product Safety and Free Movement Code" on 8 V 2012. 
decision on imposing penalty and demolition led to procrastination of enforcement of the decision in connection with unauthorized construction for which the offender was identified. ${ }^{13}$ For example, even if the offender placed various stalls, kiosks or other unattractive structures in the central avenue of the city, in the historic district, the control body had to litigate in all court instances prior to demolition because the main defence strategy of offenders in similar cases is procrastination of the litigation which is facilitated by a number of objective or subjective reasons. As it becomes clear from the research published on the official website of the Supreme Council of Justice in 2017 - "Problem of Justice Availability, its Causes and Solutions," finalization of litigation in all court instances takes between 19 and 21 months even if all terms established by law are observed, provided that during consideration of the case the parties did not enjoy the right of appeal of interim decisions or if such opportunity did not occur. In case of single use of the private complaint, the term established for the litigation offered by law is increased by at least 2 months. However, according to the logics of the same research, while the composition of the judicial system was procrastinated and a particularly large number of cases were filed to the court in 2011-2016, consideration of the case is procrastinated even more. ${ }^{14}$

${ }^{13}$ A similar regulation is currently applied in Poland, which leads to, inter alia, procrastination of demolition of constructions carried out without a permit on state-owned land parcels. In particular, according to Article 48 of the Building Law (see BUILDING LAW of 7 July 1994), construction carried out without a permit shall be subject to demolition and the decision on demolition shall be subject to appeal, which suspends the act. At the same time, control bodies are obliged to give a time period to the offender for elimination of the offence and thereafter for voluntary implementation of demolition. For example, in one case in the city of Poznan, on 13 VI 2014 the offender was instructed to arrange the document and/or carry out demolition at 170, Piatkowska Street where a car wash constructed without a permit was overlapping a part of the sidewalk. As a result of inspections carried out on 1 X 2015 and 17 II 2016 it was established that demolition was not carried out. On 13 III 2016 it was established that the demolition was not carried out. On 13 III 2016 a penalty in the amount of 155430 zloty (about 100000 GEL) was imposed on the offender for failure to carry out demolition and at the same time, a time limit was given to the offender to voluntary demolition. This fact makes it clear that the problem of timely implementation of demolition is identical for Poland. See Powiatowy Inspektor Nadzoru Budowlanego dla Miasta Poznania, DECYZJA \#242/2014, 13 VI2014 Powiatowy lnspektor Nadzoru Budowlanego dla Miasta Poznania, Postanowienie \#97/2016, 18 III 2016.

14 "Problem of Justice Availability, its Causes and Solutions," Supreme Council of Justice, Tbilisi 2017, https://bit.ly/2BfgpDO (accessed: 8 X 2018). 
Against this background, the regulation established by paragraphs 3 and 4 of Article $25^{15}$ had to become an effective tool against unauthorized construction carried out on the land parcels owned by the state or a self-governing unit, as the control body would be given an opportunity not to suspend enforcement of the decision regarding demolition even if this decision was appealed in the court. Also, the control body was granted powers to immediately demolish the buildings and structures built by unidentified persons, i.e. persons trying to escape from the representatives of control bodies for avoiding responsibility, not to answer phone calls, not to accept official mail, not to appear before control bodies and not give explanations regarding carrying out of unauthorized construction etc. Part 16 of Article 25 of the Product Safety and Free Movement Code ${ }^{16}$ grants the control body the power to adopt a decision on demolition of an illegal construction where the offender cannot be identified.

In addition to the effective enforcement mechanism, the above norm established another significant exception in the proceedings related to the construction offence. In particular, this is related to the obligation of the control body to give the offender reasonable time for the elimination of the offence before sanctions established by the law are implemented, the conditions whereof shall be reflected in a relevant document known as a directive. In this case, due to the fact that the precondition for immediate enforcement of demolition is a non-identified offender, naturally, there is nobody to whom the control body can give time for the elimination of the offence. Thus, in this case the need for a relevant directive which is a legal basis for the reduction of the proceeding timeframes has been excluded.

In the event that the control body identifies the person carrying out illegal construction on the land parcel owned by the state or a self-governing unit, in accordance with part 4 of Article 25 of the Product Safety

15 The same norms are contained in the Georgian Code on Spatial Planning, Architectural and Construction Activities Code adopted on July 20, 2018, paragraphs " $b$ " and "v" of part 2 of Article 127, as well as part 4 of Article 128 of the same Code which became effective from 3 VI 2019.

${ }^{16}$ Part 3 of Article 25 of Product Safety and Free Movement Code: "3. If a person implementing an unauthorised construction cannot be identified and the land is the property of the state and/or a self-governing unit, an authorised body shall, without issuing a directive, adopt a decision to demolish the unauthorised construction. Appealing the decision shall not suspend its effectiveness." 
and Free Movement Code, ${ }^{17}$ it shall make a decision to carry out demolition and impose penalty. In such a case, the offender will be given time for the elimination of the offence specified in the directive and if the offender fails to voluntarily demolish the construction carried out without permit, the above decision shall be issued. It is noteworthy that an appeal of the decision does not suspend enforcement of the decision on demolition, while in respect to penalty - enforcement is suspended.

\section{Legal regime of suspension of immediate enforcement of the decision on demolition - court practice and recommendations}

Despite the fact that an appeal of the individual administrative act issued on the basis of part 4 of Article 25 of the Product Safety and Free Movement Code does not suspend its effect in the part of demolition, the court often exercises the powers granted by the procedural legislation to suspend the effect of the appealed individual administrative legal act, however, this power cannot be considered to be absolute and it may be used only in specific and particular cases. In the reviewed case we are interested in the power granted to the court to suspend the effect of such individual administrative act the effect whereof is not suspended by the appeal, i.e. which falls within the list provided in Article 29 of the Administrative Procedure Code. According to this Article, an appealed individual administrative act shall not be suspended

- if postponing the execution causes significant material damage or poses a significant risk to the public order or security;

- if an administrative body has rendered a written justified decision on immediate execution, or if

- there is a necessity for urgent execution. In each case, the administrative body is obliged to substantiate the above circumstances. In addition, the act shall not be suspended if the above is determined by the law. In the reviewed case, such provision is envisaged by part 4 of

${ }^{17}$ Part 4 of Article 25 of Product Safety and Free Movement Code: "4. If a person conducting unauthorized construction is identified and the land is the property of the state and/or a local self-governing unit, an authorized body shall, based on a directive issued and the inspection report drawn up, adopt a decision to demolish the unauthorized construction and to impose liability under the legislation of Georgia upon the offender. Appealing the decision shall not suspend its effectiveness with regard to the demolition." 
Article 25 of Product Safety and Free Movement Code. Therefore, the decision in the part of demolition of unauthorized building on the land owned by the state and/or self-governing unit will not be suspended by appealing it.

Regardless of the above, part 3 of Article 29 defines the powers of the court to make a decision to suspend an individual administrative-legal act or its part upon request of a party in certain cases. For this purpose, there should be a justified doubt regarding lawfulness of the individual administrative legal act or if urgent execution of such an act may significantly damage the party or make protection of his/her legal rights and interests impossible.

In one case, even though an illegal construction was carried out on a state land in Tbilisi, the fence and the major fence adjacent to the house were beyond the red cadaster lines. In this case, the Court of Appeals relied on parts 1 and 3 of Article 29 and suspended the decision of the Municipal Inspection in the part of demolition and stated that the grounds defined by part 3 of Article 29 were evident and, in particular, that there was a justified doubt regarding the lawfulness of the appealed decision because the Claimant claimed that the Inspection had violated law when rendering this decision. At the same time, the court said that this case had to be evaluated at the consideration stage of the case on the merits. As the second ground, the Court pointed out that the case of demolition would damage the Claimant to such extent that if the unlawfulness of the decision on demolition were to be established in the future, it would not be able to protect legitimate rights and interests. ${ }^{18}$

In order to evaluate the expediency of this decision, it should be mentioned that when referring to part 3 of Article 29 the court explained that the lawfulness of the act and the doubt regarding its lawfulness are checked during the consideration of the case on the merits. Therefore, it is difficult to identify how the court legitimatizes the doubt regarding the lawfulness when it refers to the impossibility of its evaluation as it is the subject of consideration of the case on the merits. On the other hand, when another ground defined in part 3 of Article 29 is referred to in connection with the fact that after the demolition of the fence and the door the Claimant will not be able to protect legitimate rights and interest, several circumstances should be taken into consideration. First of all, the specific nature of the "construction offence" should be considered,

${ }^{18}$ Ruling of Tbilisi Court of Appeals, case \#3B/177-17, 24 II 2017, p. 5-6. 
which first of all implies a definition of the reasonable time limit for submission of documents confirming the lawfulness of the disputable building and structure for the violating party and making the decision on penalization and/or demolition only if such documents cannot be submitted. In addition, Article 63 of Resolution of the Government of Georgia On the Procedure of Issuing a Construction Permit and the Permit Conditions No. 57 dated March 24, 2009 envisages the possibility of issuing a permit for an illegal construction already carried out only in the case of submission of the payment slip of the penalty intended for this purpose. In other words, if the fact of an illegal construction of a fence and door were confirmed in the considered case, the Claimant would not be able to obtain a permit for it without payment of penalty established for this purpose which equaled to 10000 GEL in the considered case (as of today, this penalty equaled to 25000 GEL). In certain cases, from the financial point of view, demolition may be even better for the offender, because before obtaining a permit in the future, the penalty payment slip will not be necessary, and this will reduce the damage in the considered case by 10000 GEL.

Notably, Tbilisi Municipal Inspection has not submitted appropriate evidence either in the above mentioned case or in other court cases on which court judgments were issued, which would make the court expect that in such a case the buildings and structures constructed without a permit may be subject to obtaining a permit in the future at least theoretically, i.e. to what extent they comply with the general plan and the established functional zoning of the city which is the most significant issue to evaluate the extent of threat which may be posed to legitimate interests of the Claimant in case the decision on demolition is not suspended. The compliance of the disputable territory and buildings and structures located on it with the general plan and/or the territory development and usage rules as the precondition for obligation of demolition is not approved by a Tbilisi construction control authority. For example, in the practice of the construction control body of the city of Poznan, Poland, ${ }^{19}$ in addition to the obligation to submit other documents before a decision on demolition is adopted, there is also an instruction calling for an opinion of an authorized body regarding the compliance with the general plan, which in my opinion is also directly

${ }^{19}$ Powiatowy lnspektor Nadzoru Budowlanego dla Miasta Poznania, DECYZJA \#242/2014, 13 VI 2014, Powiatowy lnspektor Nadzoru Budowlanego dla Miasta Poznania, Postanowienie \#102/2016 22.03.2016, BUILDING LAW 7 VII 1994, Article 48, 2. 
related to the discussion on the suspension/non-suspension of the demolition process. According to the norms of the Polish construction law, the decision on demolition represents an exception and it is possible to make it only if the performer of an illegal construction cannot legalize the building and structure (architectural design, document confirming lawfulness of the land, certificate from the respective entity that the territory corresponds to the construction zones defined by the general plan, as well as various expert conclusions based on which the illegal building and structure may be legalized will be submitted to the control body after discovery of violation) and the control body issues a decision on demolition..$^{20}$ A permit confirming compliance with the substantive law excludes taking supervisory measures in Germany, too. In the opinion of Professor Ulrich Stelkens, in such a case it is necessary first to give the construction owner an opportunity to make an initial formal application for its construction design to be able to legalize it later. If such an opportunity is missed, there will be no grounds for preventing the application of construction supervision measures. ${ }^{21}$

If in the justification of the decisions on immediate enforcement, the control bodies specify and substantiate that the illegal building and structure contradicts the general plan of urban development which excludes the issuing of a permit, there will be a solid basis to conclude that there is a likelihood that the building and structure constructed without a permit may not become legal in the future either. Accordingly, logical grounds for suspension of the demolition process will be excluded and the outcome related to the violation of legitimate rights and expected damages will be easily predictable. Thus, an analysis of certain cases has shown that control bodies should take more responsibility when it comes to obtaining all relevant evidence, of which some may even be proved through a simple visual observation in the course of administrative proceedings related to a construction law offence (for example, the website of Tbilisi Architecture Service is available to anyone wishing to evaluate the location and functional zoning of a certain piece of land and to find out about existing restrictions, etc. (see Tas.ge - interactive map)) and submit such evidence to the court.

${ }^{20}$ K. Aleksandrowicz, Property Development Process in Accordance with the Polish Building Law, Polish Information and Foreign Investment Agency (PAIiIZ) 2016, p. 25.

${ }^{21}$ U. Stelkens, Construction Supervision in Germany, Forum Materials of Tbilisi State University Institute of Administrative Sciences, "Perspective of Administrative Sciences" 2017, \#3, p. 46. 
In addition to part 3 of Article 29 of the Administrative Procedure Code, Article 198 of the Civil Procedure Code which defines measures for securing a claim is also used for the purpose of suspension of the similar decision of the Municipal Inspection on demolition by the court. The court relies on the above Article if the writ of execution is already issued for the decision on demolition and the National Enforcement Bureau has already initiated enforcement proceedings in this respect. Certainly, we cannot consider a writ of execution as the individual administrative legal act and failure to apply Article 29 to it should be evaluated correctly, however application of Article 198 of the Civil Procedure Code raises questions.

In one case, due to the construction carried out without a permit on the state-owned land parcel in Tskneti village, Tbilisi Municipal Inspection made a decision to demolish the building constructed without a permit on the basis of part 4 of Article 25 of the Product Safety and Free Movement Code. However, Tbilisi City Court suspended the enforcement proceedings initiated on the basis of the writ of execution issued in connection with the case in the part of demolition and for this purpose, applied sub-paragraph " $\mathrm{d}$ " of part 2 of Article 198 of the Civil Procedure Code, ${ }^{22}$ which provides that measures for securing a claim may include: " $d$ ) restricting other persons from transferring property to the defendant or from performing any obligation towards the defendant," and in another case related to the decision made on the basis of part 4 of Article 25 of the Product Safety and Free Movement Code by Tbilisi Municipal Inspection on penalization of the structure arranged on the Mtkvari river in Tbilisi and demolition of the structure, ${ }^{23}$ the Court referred to part 3 of Article 198 of the Civil Procedure Code and suspended the enforcement proceedings. This Article defines that measures for securing a claim may include:

"3. A court may apply other measures as well if so required to secure a claim."

It is noteworthy that in both cases the court did not take into consideration Article 36 of the Law "On Enforcement Proceedings" which is related to the possibility of suspension of enforcement proceedings by the court and provides a specific list of cases when the court is authorized

${ }^{22}$ Ruling of the Board of Administrative Cases of Tbilisi Civil Court dated 31 V 2017, case 1946460 , p. 3.

${ }^{23}$ Ruling of the Board of Administrative Cases of Tbilisi Civil Court dated 3 V 2018, case \#3/2368-18, p. 4 . 
to suspend the enforcement process. According to the above Article, it is possible to suspend the enforcement process by the court where an appeal is lodged against the action of the body (official) authorized to hear the case of an administrative offence until the decision is made; Article 36 also envisages a possibility of the suspension of the enforcement process in the event of liquidation of a corporate debtor, until its legal successor is identified. Article 36 does not contain any record about suspension of demolition of unauthorized construction on the land parcel owned by the state and/or self-governing unit. Accordingly, referring to Article 36 in decisions on such suspension by the court without any substantiation raises questions, because relying on Article 36 is rather an argument to be used for the opposition at the court as the sole Article in the Georgian legislation containing a specific and detailed list of cases when the court may suspend the enforcement process. If the legislators were willing to have general powers of suspension of enforcement process by the court, they would not have provided Article 36 in the form of this specific list and would state that the court may suspend the enforcement process at its own discretion, on the basis of a substantiated petition.

Also, there is a clear inconsistency regarding the application of Article 198 as the ground for the decision on demolition. Firstly, it is absolutely unclear how suspension of the demolition enforcement process is related to the case defined by sub-paragraph " $\mathrm{d}$ " of part 2 of Article 198 concerning the prohibition of performance of an action specifically on the part of the debtor in favor of the creditor and it is applied only in the event when various claims are raised in respect of the creditor and the creditor has no assets except the assets in respect of the debtor to secure them. ${ }^{24}$ Thus, proceedings of enforcement of the decision on immediate demolition by Tbilisi Municipal Inspection cannot fall within the context of the norm referred to by the court and naturally, it

\footnotetext{
${ }^{24}$ A case from the court practice and the ruling of the Board of Civil Cases of Tbilisi Civil Court dated 7 IX 2016, case \#2/22276-16 (also, ruling of the Board of Civil Cases of Tbilisi Court of Appeals dated 30 III 2016, case \#2B/1540-16) may serve as an example, when doctors of one hospital who had a dispute regarding imposition of payment of unpaid salary upon their employer, prohibited the employer's creditor (upon which payment of certain amount was imposed in favour of the employer) to pay the amount, as it was the sole asset and the sole financial source of receiving the amount in case the doctors won the court case, which was agreed by the court of the first instance as well as the Court of Appeals. In this case, the prohibition was based on sub-paragraph " $\mathrm{d}$ " of paragraph 2 of Article 198 of the Civil Procedure Code of Georgia.
} 
would be better if it had been more clearly specified in the court ruling. It is noteworthy that a legal evaluation of the application of this Article had not been made by the Court of Appeals either. ${ }^{25}$ From the case materials it is expressly established that the area of carrying out unauthorized construction in Tskneti settlement (the cadaster unit where an unauthorized construction was carried out) falls within the landscape recreation zone. Its content is defined by paragraph "a" of part 2 of Article 15 of the resolution of Tbilisi Municipality Sakrebulo No. 14-29-E dated May 24, 2016: "Landscape-recreation sub-zone which includes, as a rule, the territory of the natural landscape or valuable artificial landscape beyond the developed areas of Tbilisi"; In accordance with sub-paragraph "a" of the first part of Article 16 of the same Resolution, in this zone: "It is not allowed to carry out any construction except the buildings and structures ensuring its functioning in accordance with the legislation and also, placement of religious buildings and structures on the basis of a special (zonal) agreement."

Notably, Tbilisi Property Management Agency sells such territories only on the basis of recommendations of Tbilisi Municipality City Hall Urban Service and in compliance with the current legislation. ${ }^{26}$ Therefore, on the example of Tskneti settlement we may say that based on the applicable normative acts and having considered the existing zoning, the settlement in question cannot be considered to be a construction land parcel and it is clear from the beginning that under the existing legal regulations none of the administrative bodies will be able to give positive recommendations for construction of residential houses in the landscape recreation zone. Accordingly, it is certain that it will also be impossible to carry out a legal construction on such territories in the future - which makes the court's statement that a failure to suspend the decision on demolition may damage legitimate interests of the Claimant, render the court decision unenforceable etc. less reliable. Considering the fact that it is prohibited to carry out any construction in the landscape recreation zone except the structures providing

${ }^{25}$ Ruling of the Chamber of Civil Cases of Tbilisi Court of Appeals in case \#3B/1456-17 dated 28 IX 2017.

${ }^{26}$ The list of property which is not subject to alienation is provided in the Law of Georgia "On Privatization of State Property, Privatization and Transfer of Local Self-Governing Unit Property with the Ownership Right" dated 30 V 1997. Article 4 of this Law provides a list of this property, including: water resources (at the example of Mtkvari river) and forest fund (at the example of landscape recreation space in Tskneti settlement). 
this zone with paths, roads and infrastructure required for proper management and maintenance of this zone, it is unclear what legal perspective may exist which will allow us to put the interests of the Claimant above the state regulations and restrictions. These interests cannot be evaluated as legitimate interests because it is difficult to call an interest legitimate when it is directed at a construction on the construction territory restricted by the current legislation! The existence of a legitimate interest in similar cases depends on the possibility of carrying out construction legally or to place the illegally carried out construction within a legal regime. Therefore, the lawfulness of interest depends on the existing legal framework which is defined by general plans, rules of use and development of the area, or other legislative restrictions imposed by the state. The precondition of admissibility of filing a claim envisaged by Article 22 of the Administrative Procedure Code is defined as follows: "if the administrative decree or any of its part directly (individually) injures legitimate right or interest of the plaintiff, or unlawfully restricts his right". ${ }^{27}$ It is interesting how the existence of legitimate rights or interest of the plaintiff should be substantiated in similar cases. When the court refers to the restriction of legitimate rights or interest of the plaintiff as the reason for suspension of demolition, we should consider that this implies: exercising of its rights protected by law, protection of its legitimate rights since also, its legitimate rights and interests should be directly (individually) damaged by non-performance and/or performance of any action by the administrative body. At the same time, the above interest should be specific, legitimate and respected..$^{28}$

${ }^{27}$ According to the explanation of the Cassation Court: Application to the court is related to only to the actual need of protection of "its" right or freedom and due to this, only the person having an actual interest for it shall enjoy the procedural right to file a claim at the court and at the same time, this interest must be legitimate. Possibly, a person thinks that he/she has such interest and applies to court, but such subjective attitude of the person does not mean that objectively he/she is actually interested in terms of conducting the process. Admissibility of claim in the administrative process serves clarification of this issue and its purpose is before starting consideration of the case on merits, together with a number of necessary issues, in advance, identify, whether filing a claim has a legitimate interest. Please refer to the ruling of the Chamber of Administrative Cases of Supreme Court of Georgia dated 26 X 2018, case \# BS-574-574(KS-18), http://prg.supremecourt.ge/DetailViewAdmin.aspx (accessed: 8 XI 2018).

${ }^{28}$ Ruling of the Chamber of Administrative Cases of Supreme Court of Georgia in case No. \#BS-857(KS-18) dated 26 X 2018, http://prg.supremecourt.ge/DetailViewAdmin. aspx (accessed: 8 XI 2018). 
Under these conditions, the scope of court powers, the expediency and even fairness of the rendered decisions are interesting. It is interesting to share the approach of the German court in similar cases. In connection with one case which was related to the evaluation of the lawfulness of the decision on demolition by Rheinland-Pfalz Higher Administrative Court, it was mentioned that subjective circumstances of the plaintiff, such as age, economic situation, length of illegal ownership of real estate should not be considered when making such decisions. In particular, according to the court: "When adopting a decision by the Construction Supervision Unit at its own discretion, consideration of personal and economic conditions of the person would eventually lead to putting the person who was acting in violation of law in the privileged situation [...]. The person who acts lawfully and requests a license (construction permit - author) before starting to use is deprived of this means of consideration, because construction material law, as it is being attached to land, considers such thing to be inadmissible. Thus, the person who starts using the land parcel in violation of law, would be placed in a privileged situation had the state body not considered his/her personal circumstances at the moment of adopting a discretional decision as compared to the person who acts in accordance with the law and suspends usage if norms of law prohibit him/her to use. However, the interpretation of law which brings us to the conclusion that a law-abiding citizen is "silly" should be avoided. This does not mean that any possible difficulty should be completely ignored by a person. In contradiction to it, the applicant may raise the issue of personal circumstances in the context of the following enforcement proceedings and request suspension of the proceedings." ${ }^{29}$ Professor Ulrich Stelkens offers an explanation on the same issue. According to him, "It can make such decision due to expediency, considering specific aspects of an individual specific case. At the same time, it shall not be objected to if the authority interferes for the purpose of restoration of lawful situation, even if in such case the investments already carried out by the construction owner are devaluated. Otherwise, the construction owner would have been able to ignore the applicable construction-legal rules by creation of completed facts. The construction law would be transformed into the so-called "Law of the Silly". It would exist for those

${ }^{29}$ Refer to Decision of Rheinland-Pfalz Higher Administrative Court dated $11 \mathrm{X}$ 2007-1 A 10555/07 - Rn. 21. 
who are silly and observe it and not for those who are rather impudent and can violate it." 30

The above explanations are significant when we are talking about the expediency of suspension of enforcement proceedings in connection with the process of demolition the possibility of suspension whereof is not recognized by Article 36 of the Law of Enforcement Proceedings. Also, even assuming that if the plaintiff requests to suspend the decision on demolition before initiation of enforcement proceedings, in particular, within the framework of appeal of the individual administrative-legal act, in the course of assessment of its future and possible damage, personal subjective circumstances (plaintiff's age, economic situation) should be taken into consideration which will be juxtaposed to objective circumstances named by the issuing authority of the individual administrative-legal act - in particular, what is the purpose of immediate enforcement of the decision on demolition, as well as whether there is a theoretical chance in the future that the building and structure may be placed within legal framework (whether a construction permit may be issued for it). It is also important to take into consideration how the legitimate interests of the owner (state) should be balanced considering the factual condition, while in the course of suspension of litigation and the enforcement process, it is restricted for 19-21 months to administer as the owner and exercise the ownership right and therefore, it remains responsible for observance of safety norms during the construction, appearance of the city and other public interests.

For example, by the court ruling dated May 3, 2018 when the structures constructed on Mtkvari river were demolished, unlike the example of Tskneti settlement, the disputable structure was constructed on Mtkvari river in the historic and touristic area of the city and therefore, this security measure deprives the municipality of the right to ensure protection and maintaining of the city appearance for several years at least, as well as of the right to protect the state's property right to the river assigned to the state water fund which is guaranteed by Article 6 of the Law "On Water": "Waters within the territory of Georgia are state property and shall be allotted for use only. Any action directly or indirectly violating the state property right to water shall be prohibited.

${ }^{30}$ U. Stelkens, "Construction Supervision in Germany", Forum Materials of Tbilisi State University Institute of Administrative Sciences, Prospective of Administrative Sciences \#3, 2017, p. 46 (also, refer to Decision of the Lower Saxony Supreme Administrative Court (Land) dated 28 II 1983-6A 69/62). 
Article 20 of the same Law defines that within the river protection zone it is prohibited to construct, except for cases directly determined by law. Therefore, when an illegal construction is carried out on similar territories, it is noteworthy and important in the course of suspension of the process of enforcement of the decision on demolition by the court to evaluate the existing legislative regulations, purpose and significance of the state-owned territories. Accordingly, in such cases it is significant to juxtapose the interests to be protected which we do not encounter in the materials of the Georgian court practice.

\section{Conclusions}

As a conclusion, we can outline the circumstances which should be taken into consideration when making a decision on suspension of enforcement proceedings by the court:

- Who is the owner of the territory where the construction was carried out because the precondition for application of part 4 Article 25 of the Product Safety and Free Movement Code is created by an illegal construction carried out on the land parcel owned only by the state or self-governing unit;

- Whether the territory falls within any particular zone listed in Article 44 of the Product Safety and Free Movement Code;

-Whether the construction is finished. If the construction is finished, of course, there will be more legitimate interests in maintaining it and the potential amount of the possible future damage of the offender will increase. In the case of the "under construction" status, on the contrary, the risks common for the structure under construction, no entry for third persons, its appearance, especially if the building under construction is located in the historic part of the city, should be taken into consideration.

-Whether it is theoretically possible to place the building and structure constructed without a permit within the legal regime, to what extent their existence corresponds to the general plan of the city and the conditions of use and development of the territory. This issue is also significant to evaluate to what extent the property in general is subject to alienation and further, to what extent it is possible to issue a construction permit for it.

- Personal subjective circumstances of the plaintiff, in particular, his/ her social status, age, health condition and other factors. 
In my opinion, in certain cases, in particular, in the landscape recreation zones, on the riverbed, in the cultural heritage protection zone etc. such restrictions of the state to carry out demolition by the court would be justified only in the event when the proceedings are carried out quickly and effectively and when consideration of such cases is carried out in accelerated manner. It will be logical if respective changes are made to the procedural legislation and similar to special terms defined by part 3 of Article 59 of the Civil Procedure Code, the proceedings related to the resolution envisaged by part 4 of Article 25 of the Product Safety and Free Movement Code are restricted by limited timeframes. In particular, part 3 of Article 59 of Civil Procedure Code provides that: "except cases of restoring an immovable thing from illegal possession which shall be reviewed within not later than one month." The period of acceptance and review of the cassation complaint is reduced from 6 months to 2 months. Also, under Article 268 of the same Code, cases of restoring an immovable thing from illegal possession shall be enforced immediately, i.e. the decision made by the court of the first instance shall be subject to enforcement if such decision is made by the court upon request of a party. Notably, the purpose of part 3 of Article 59 is the effective protection and sale of private property, therefore, the issue to be reviewed and this Article have the common goals in the part of the protection and exercise of the State's ownership right.

In case of enforcement of the above legislative regulations, an opportunity of practically a threefold reduction of the 21-month term required for the legal proceedings is achieved. Thus, the control bodies should initiate making respective changes to the procedural legislation for the purpose of quicker and more effective proceedings in similar cases. Otherwise, it is impossible to achieve the goals stipulated in part 4 of Article 25 which is also a stimulating factor for the offenders because it contributes to increasing their motivation to build various construction forms (construct in 1 night to avoid suspension by the control body), and later use them for residential or commercial purposes, and at the same time, procrastinate the process of demolition by means of litigation. This should be considered as a serious obstacle to exercising the construction control and should be overcome either by changing the practice by the court in a particular case (this implies illegal construction carried out on the territories restricted for construction which should be considered as constructed without permit) and/or by immediate legislative changes which will establish limited timeframes for consideration of similar disputes. 


\section{SPECIAL CONDITIONS SANCTIONING DEMOLITION OF BUILDINGS AND STRUCTURES CONSTRUCTED WITHOUT A PERMIT ON THE STATE-OWNED LAND PARCEL RESTRICTED FOR CONSTRUCTION}

\section{S u m m a ry}

The article addresses special conditions sanctioning demolition of buildings and structures erected without a permit on the state-owned land parcel restricted for construction according to the Georgian legislation and the practice of suspension of enforcement proceedings of similar resolutions by the court. It reviews the regulation envisaged by part 4 of Article 25 of Product Safety and Free Movement Code, according to which buildings constructed on state and/or self-governing unit-owned land parcels are subject to demolition and an appeal of the resolution on demolition does not suspend its enforcement. Despite the above, within the procedural legislation, the court suspends the enforcement process in the part of demolition. The article assesses the prospective of placing such buildings and structures within the legal framework in the future (compliance with the general plan, functional zoning, rules of development and use of the territory), i.e. their eligibility for obtaining a permit in deciding on the suspension/non-suspension of the demolition enforcement process. In Georgian practice, this factor is not accentuated by the construction control body when making a resolution on demolition, nor does the court evaluate it, which is the most significant circumstance in the process of making and enforcing such type of resolutions.

Examples from the Polish and German practice where a permit allowing illegal buildings and structures to be admitted (as complying with the substantive construction law) is one of the most significant preconditions for making a resolution regarding demolition are presented and discussed.

The circumstances to be considered in the course of suspension by the court of demolition of buildings and structures illegally constructed on state and/or self-governing unit-owned land parcels are also described, and legislative changes/ amended regulations for the sake of avoidance of procrastination of such type of demolitions have been recommended.

Keywords: construction law - building without permit - demolition - illegal construction/structure 